\title{
COMPLEX SHORE ZONE EVALUATION OF LAKE VELENCE, HUNGARY
}

\author{
BOROMISZA, Zs. \\ Corvinus University of Budapest, Department of Landscape Protection and Reclamation \\ 1118 Budapest, Villányi út 29-43., Hungary \\ (phone: +36-1-482-6510, fax: +36-1-482-6383) \\ e-mail: zsombor.boromisza@uni-corvinus.hu \\ (Received $28^{\text {th }}$ November 2011; accepted $22^{\text {nd }}$ December 2011)
}

\begin{abstract}
Considering the social demands lakeshores have many special functions, such as: landscape protection functions (e.g. special habitat, buffer-function) and land use functions (e.g. recreation-tourism, public places. The shore of Lake Velence (Hungary) was evaluated according to four viewpoints: pressures, naturalness, buffer-function and suitability for changing shore fortification. A detailed survey of the lakeshore was made by dividing the shoreline into $100 \mathrm{~m}$ long and $50-50 \mathrm{~m}$ wide sections to land (riparian zone) and to water (littoral zone) directions. According to the results low pressures, being characteristic for more than half of the lakeshore are partially due to the land use peculiarities. It is mainly the sections near boat harbours and ship docks which have connection between pressures and naturalness and which are pressured to critical extent, being heavily modified at the same time. Areas with good buffer-capacity are typical between the reed-works of Pákozd and the boat harbour in Sukoró. It is mainly a short shore section in Velence that can be considered to have advantageous features for changing shore fortification.
\end{abstract}

Keywords: lakeshore assessment, shoreline restoration, Lake Velence, landscape architecture

\section{Introduction}

In Hungary the full area of standing waters makes approx. $1685 \mathrm{~km}^{2}$ (almost $2 \%$ of the country's territory). About $75 \%$ of the 3500 registered standing water bodies are artificial lakes. There are 296 standing water bodies exceeding 50 ha, out of which 123 are artificial ones (KvVM, 2009b). The increased use resulted in disadvantageous change of the chemical and ecological status at several places all over the world that will become even worse through the global climate changes in most regions.

These environmental problems occur more intensively in the Hungarian shallow lakes having primary recreational utilization in many cases. Proper management of lakes is often hindered by the missing information and knowledge of their status, especially their most sensitive part, i.e. lakeshores. Considering the social demands lakeshores have many special functions, such as: landscape protection functions (e.g. special habitat, buffer-function) and landuse functions (e.g. recreation-tourism, public spaces). There are several factors that affect lakeshore conditions: water-level regulation, shore- and lake-bed regulation, shore-use (which may involve structures, buildings on the shore), as well as external effects (e.g. climatic change).

Though several national programs, plans (KvVM, 2007, 2008, 2009a, 2009b) set objectives, tasks concerning lakeshores, at present there is no proper technique to assess, evaluate them with a complex approach considering both landscape-ecology and landuse, at the same time. 


\section{Review of literature}

The assessment methods of lakeshores go back to the assessment traditions of standing waters and wetland habitats having mainly an ecological approach. The significance of wetland habitat nature protection that marks also lakeshores and the pressured functions resulted in many methodologies (e.g. Adamus et al., 1991; Bain et al., 2000; Fenessy et al., 2007). Innis and her colleagues (2000) examined definitely the assessment methods of habitats at the border of surface waters - land, specifying surveys, assessments and evaluations. While classifying wetland habitats several authors term transitional habitats on the border of standing waters special type (Brinson and Malvárez, 2002; Cowardin et al., 1979; Smith et al., 1995) and refer to lakeshores as potential wetland habitats (Lehner and Döll, 2004). Out of the above the guidance (Common implementation strategy, Wetlands horizontal guidance, 2003) dealing with the significance of wetland habitats, made in connection with EU Water Framework Directives (WFD), is of high importance, specifying lakeshores' wetland habitat as relevant ecosystems as to the goals of the Directives.

In the international professional literature one can find sources which elaborate both the ecological and landuse significance of lakeshores (Ostendorp et al., 2004; Pieczynska, 1990; Schmieder, 2004; Strayer and Findlay, 2010). Some authors deal with the role of landzone-type processes, e.g. buffer/biofilter (Boyd, 2001; Davies and Lane, 1996; Fischer and Fischenich, 2000; White, 2010). Most lakeshore researches focus on the above functions, in addition to other impacts of lake-utilization. The analysis of Engel and Pederson (1998), Löffler (1990), Ness (2006), Strayer and Findley (2010) regarding the effects of lakeshore-development belong to the most complex ones, similarly to the works of Schmieder (2004) on human disturbances of Europe's lakeshores.

Most of the authors processing survey, assessment and evaluation methods of lakeshores treat shores as part of surveying wetland habitats (including lakes) (e.g. USEPA, 2007; Rowan, 2008). A part of the literature regarding survey of lakeshores aims at assessing a certain feature of the lake concerned. The assessments and evaluation methods in the USA that focus on defining the ecological sensitivity of lakeshores (McPherson and Hlushak, 2008; Perleberg et al., 2009) are well applicable also for the Hungarian landscape architecture. In connection with WFD, Ostendorp (2004) studied the assessment methods of lakeshores and a method has been elaborated also in Italy to evaluate the ecological status of lakeshores (Siligardi et al., 2010). Furgala-Selezniow et al. (2011) made assessment of a lake in Poland with regard to recreation - tourism landuse and pressures at the shore.

The hydrobiological science realized quickly the ecological significance of lakeshores in Hungary, too, as one can see in the scientific researches on Balaton. Olga Sebestyén has an outstanding professional activity concerning lakeshore researches. She deals with conditions, processes of Lake Balaton's shore in many works (Entz and Sebestyén 1942; Sebestyén, 1943, 1957, 1963). Felföldy $(1981,1986)$ also deals with the importance that lakeshores have in the biology of lakes. The hydrobiological researches of lakes (Baranyi, 1980), served first of all as scientific basis for the large lakes' recreational developments (Bökfi et al., 1987). In the period between 1970-1990 utilization and water-quality improvements were made partly by large-scale human interventions, shore- and lakebed regulations - many authors deal with these processes, facilities and results (Goda, 1991; Ligeti, 1976; Szappanos, 1978; Zorkóczy, 1985). 
The assessment methods of the Hungarian lakeshores appeared mainly in connection with plans (KSzI, 1998). A fundamental change was induced by the regional plan made for the Lake Balaton's recreational district (VÁTI, 1998). This plan deals separately with lakeshore settlements, besides, it draws the attention to the landuse conflicts concerning shore-zone being ,highly sensitive to surface pollution”, to the „overuse" of land-zone and ordered to make so called "lakeshore-restoration plans". As to Lake Velence conceptions and programs have been elaborated since the "70s connected with the shore regulation (KDTVIZIG, 1974). At the Faculty of Landscape Architecture of Corvinus University Budapest assessments have been made on the mining lakes in Délegyháza since 2009 by 20x30 m survey plots of the shore. The features of each and every plot were registered in a data-sheet, while separate assessments were made on the shore's wider surroundings, the riparian zone, the riparian slope as well as on the littoral zone (Sallay and Boromisza, 2011).

\section{Materials and methods}

\section{Study area}

Lake Velence is one of the largest Hungarian shallow lakes $\left(24 \mathrm{~km}^{2}\right)$, having significant natural values, for which there are continuous development ideas, yet the knowledge of the present, exact status of lakeshore is missing. The lake has a length of $10.8 \mathrm{~km}$, and an average width of $2.3 \mathrm{~km}$ (Baranyi, 1980). The full length of legal shoreline (including piers) makes $40.67 \mathrm{~km}$, belonging to four settlements (Gárdony, Velence, Sukoró, Pákozd). The average water depth is $1.45 \mathrm{~m}$ (Szilágyi et al., 1989), on basis of the data available, similar water depth has been typical since its origin (Bendefy, 1971). The lakebed has almost steady depth, more significant breaks originated through dredgings, the maximum water depths makes about $5 \mathrm{~m}$. The selection of the study area is justified by the varied shore conditions caused by diversified natural and landscape features and by the - relatively big - size of the lake. For the long-term utilization of the lake it is essential to consider the lakeshore's landscape and natural features.

\section{Lakeshore evaluation method}

The evaluation sets the objective to establish the lakeshore's landscaping and regulation by means of special evaluation points of view. When defining the evaluation method it is supposed to characterize the shore's landscape-ecological and landuse features, as well as the landscape protection functions, besides being repeatable and applicable for other lakes (Boromisza, 2010). The lakeshore's detailed survey was made by dividing the legal shoreline into $100 \mathrm{~m}$ long sections to land direction (riparian zone) and to water direction (littoral zone), both in a distance of 50-50 m. By this method 351 assessment plots were placed along the shoreline. During the assessments the following basic maps were used: topographic map 1:10000 (1986), colour, high-resolution ortophoto (2009) used by Central-Danubian Water Authority also for survey and qualification of reeds and the so called combined register map of Lake Velence 1:4000 (2007). As a primary assessment method on-site field survey was applied. My partial researches on the study area has been carried out since 2004, including various seasons and shore sections. Between June-September 2011, during my field survey, including the whole lakeshore the earlier results were made up-to-date and also completed. 
In the evaluation work-part the shore sections that vary in their pressures, naturalness, buffer-function and in the possibility to change shore fortification were dealt with separately. Within the individual evaluation factors the possible categories get scores (from 1 to 3 ). The highest scores (3) mean the most advantageous conditions from the given point of view. The individual evaluation factors are weighted in every evaluation aspect (between 1-3). The plots are classified into categories made according to the evaluation aspects, on basis of the scores modified by weighting. When defining categories the plots getting the highest scores are always highlighted.

\section{Pressures}

The pressures of the lakeshore (PR) were defined as below:

$$
\mathrm{PR}=\mathrm{P}_{\mathrm{sd}} \mathrm{XW}_{\mathrm{sd}}+\mathrm{P}_{\mathrm{lu}} \mathrm{xW} \text { lu }+\mathrm{P}_{\mathrm{po}} \mathrm{xW}_{\mathrm{po}}+\mathrm{P}_{\mathrm{el}} \mathrm{xW} \text { el }+\mathrm{P}_{\mathrm{hu}} \mathrm{xW} \text {. }
$$

For evaluation of the pressures the following factors were considered: shoreline development - the shape of a shoreline (sd), land use (lu), point sources of water pollution (fo), significant linear landscape elements in the riparian zone - roads, ditches, embankments (el), degree of human existence (hu).

The pressures of the shore include all human induced effects, which may involve not only pollutions, but structures or disturbing utilization forms (Csima and Göncz, 2003). The plots with higher shoreline development (higher specific pollution-exposure), with intensive utilization and human use bordered by point sources of pollution and significant linear landscape elements (non-point sources of pollution, disturbance) were considered to be the most pressured ones. Table 1 shows the evaluation factors, weight numbers, and qualification points.

Table 1. Evaluation factors and qualification method while defining pressures

\begin{tabular}{|c|c|c|c|}
\hline Evaluation factor & Qualification & Score $(P)$ & Weight (W) \\
\hline $\begin{array}{l}\text { Shoreline development } \\
\qquad(\mathrm{sd})\end{array}$ & $\begin{array}{l}\text { High } \\
\text { Moderate } \\
\text { Low }\end{array}$ & $\begin{array}{l}1 \\
2 \\
3\end{array}$ & 1 \\
\hline Land use (lu) & $\begin{array}{l}\text { Intensive (lake-dependent and not dependent) } \\
\text { Extensive (lake-dependent and not dependent) }\end{array}$ & $\begin{array}{l}1 \\
3\end{array}$ & 3 \\
\hline $\begin{array}{l}\text { Point sources of } \\
\text { pollution (po) }\end{array}$ & $\begin{array}{l}\text { Available } \\
\text { Not available }\end{array}$ & $\begin{array}{l}1 \\
3\end{array}$ & 2 \\
\hline $\begin{array}{l}\text { Significant linear } \\
\text { landscape elements in } \\
\text { the riparian zone (el) }\end{array}$ & $\begin{array}{c}\text { Considerable } \\
\text { None, less considerable }\end{array}$ & $\begin{array}{l}1 \\
3\end{array}$ & 3 \\
\hline $\begin{array}{l}\text { Degree of human } \\
\text { existence (hu) }\end{array}$ & $\begin{array}{c}\text { Much intensive in whole year } \\
\text { Much intensive in season, medium intensive } \\
\text { in whole year } \\
\text { Less intensive in whole year }\end{array}$ & $\begin{array}{l}1 \\
2 \\
3\end{array}$ & 1 \\
\hline
\end{tabular}

Classification of the possible categories: 10-16 points - lakeshore is pressured to critical extent, 17-23 points - significantly pressured lakeshore, 24-29 points lakeshore is pressured to small extent, 30 points - unpressured lakeshore. 


\section{Naturalness}

Naturalness (NA) of lakeshore has been defined as below:

$$
\mathrm{NA}=\mathrm{P}_{\mathrm{sc}} \mathrm{xW} \text { sc }+\mathrm{P}_{\mathrm{rc}} \mathrm{WW}_{\mathrm{rc}}+\mathrm{P}_{\mathrm{vn}} \mathrm{xW} \mathrm{W}_{\mathrm{vn}}+\mathrm{P}_{\mathrm{zo}} \mathrm{xW} \text { zo }+\mathrm{P}_{\mathrm{sf}} \mathrm{xW} \mathrm{sf}+\mathrm{P}_{\mathrm{lz}} \mathrm{xW} \text { lz }
$$

While defining naturalness, in addition to several features of vegetation (naturalness (vn) and zonation (zo) of the vegetation were weightly considered) also soil conditions (sc) and shore fortification (sf) are decisive. The most near-natural areas are on natural soil (without significant impervious, filled up surface), the riparian vegetation cover (rc) is high, shore fortification is most similar to natural shore (shore-wall is least similar), no structures in the littoral zone (lz), advantageous species and zonation of the vegetation. Table 2 shows the evaluation factors, weight numbers and qualification scores.

Table 2. Evaluation factors and qualification method while defining naturalness

\begin{tabular}{|c|c|c|c|}
\hline Evaluation factor & Qualification & Score $(\mathbf{P})$ & Weight (W) \\
\hline Soil conditions of riparian zone (sc) & $\begin{array}{l}\text { Impervious, filled up surface } \\
\text { Natural soil }\end{array}$ & $\begin{array}{l}1 \\
3\end{array}$ & 1 \\
\hline Riparian vegetation cover (rc) & $\begin{array}{c}<40 \% \\
40-70 \% \\
70 \%<\end{array}$ & $\begin{array}{l}1 \\
2 \\
3\end{array}$ & 2 \\
\hline naturalness of vegetation (vn) & $\begin{array}{c}\text { Fully altered } \\
\text { Moderately or slightly modified } \\
\text { Near-natural }\end{array}$ & $\begin{array}{l}1 \\
2 \\
3\end{array}$ & 3 \\
\hline Vegetation zonation (zo) & $\begin{array}{c}\text { Lack of near-natural zonation } \\
\text { Partially modified zonation } \\
\text { Near-natural zonation }\end{array}$ & $\begin{array}{l}1 \\
2 \\
3\end{array}$ & 3 \\
\hline Typical shore fortification (sf) & $\begin{array}{c}\text { Shore-wall } \\
\text { Slope-rip rapping or other fortification } \\
\text { Near natural }\end{array}$ & $\begin{array}{l}1 \\
2 \\
3\end{array}$ & 2 \\
\hline Structures in the littoral zone (lz) & $\begin{array}{c}\text { Significant } \\
\text { Less significant } \\
\text { None }\end{array}$ & $\begin{array}{l}1 \\
2 \\
3\end{array}$ & 2 \\
\hline
\end{tabular}

Classification of the possible categories: 13-21 points - heavily modified lakeshore, 22-30 points - modified lakeshore, 31-38 points - slightly modified lakeshore, 39 points - near-natural lakeshore.

\section{Buffer-function}

Buffer-function (BU) of lakeshore has been defined as below:

$$
\mathrm{BU}=\mathrm{P}_{\mathrm{sc}} \mathrm{xW}_{\mathrm{sc}}+\mathrm{P}_{\mathrm{sl}} \mathrm{xW}_{\mathrm{sl}}+\mathrm{P}_{\mathrm{wc}} \mathrm{xW}_{\mathrm{wc}}+\mathrm{P}_{\mathrm{wv}} \mathrm{xW}_{\mathrm{wv}}+\mathrm{P}_{\mathrm{rc}} \mathrm{xW}_{\mathrm{rc}}+\mathrm{P}_{\mathrm{zo}} \mathrm{xW}_{\mathrm{zo}} \text {. }
$$

For the evaluation the following factors were considered: soil conditions of riparian zone (sc), riparian slope (sl), water surface cover with emergent machrophytes (wc), width of zone covered with emergent macrophytes (wv), riparian vegetation cover (rc), vegetation-zonation (zo).

While evaluating buffer-function - as determinant landscape protection shore function - I assessed first of all how much the shore's existing features are suitable to 
retain the nutrients, sediments that come from the riparian zone (bio filter function). In addition to the higher vegetation cover (both in the riparian and littoral zones) and to the wide zone of emergent macrophytes joining the shoreline (latter was regarded as the most important factor for weighting), the vegetation diversity is advantageous feature. Because of the different nutrient uptake dynamic of the individual vegetation zones and species, the varied shore zonation was considered to be advantageous (Adamus et al., 1991; Tóth, 1982), and the slight slope (smaller surface run-off, erosion). One should have in mind that the areas filled up with typically clayey sediments (Karászi, 1984) hinder the nutrients to get into lake water due to their high adsorption capacity (mainly fixing phosphorus). Table 3 shows the evaluation factors, weight numbers and qualification scores.

Table 3. Evaluation factors and qualification method while defining buffer-function

\begin{tabular}{c|c|c|c}
\hline Evaluation factor & Qualification & Scores (P) & Weight (W) \\
\hline Soil conditions of & Impervious surface & 1 & 2 \\
riparian zone (sc) & Natural soil & 2 & \\
& Filled up surface & 3 & 2 \\
Riparian slope (sl) & $75^{\circ}<$ & 1 & \\
& $30-75^{\circ}$, varied & 3 & 2 \\
Water surface cover & $<30^{\circ}$ & 1 & \\
with emergent & $<10 \%, 10-40 \%$ & 2 & \\
macrophytes (wc) & $40-70 \%$ & 3 & 3 \\
Typical width of zone & $70 \%<$ & 1 & \\
covered with emergent & $<1 \mathrm{~m}$ & 2 & \\
macrophytes (wv) & $1-4$ m, $4-20 \mathrm{~m}$ & 3 & 3 \\
Riparian vegetation & $20 \mathrm{~m}<$ & 2 & \\
cover (rc) & $<40 \%$ & 3 & \\
Vegetation zonation & $40-70 \%$ & 1 & \\
(zo) & Lack of near-natural zonation & 2 & \\
\hline
\end{tabular}

Classification of possible categories: 13-21 points - lakeshore with poor buffercapacity, 22-30 points - lakeshore with medium buffer-capacity, 31-38 points lakeshore with good buffer-capacity, 39 points - lakeshore with excellent buffercapacity.

\section{Possibility to change shore fortification}

In this case I evaluate separately pull down of (artificial) shore fortification and a chance to make a near-natural shore, as a key issue of lakeshore-restoration. The suitable zones have been defined as below:

$$
\mathrm{CF}=\mathrm{P}_{\mathrm{we}} \mathrm{x} \mathrm{S}_{\mathrm{we}}+\mathrm{P}_{\mathrm{lu}} \mathrm{x} \mathrm{S}_{\mathrm{lu}}+\mathrm{P}_{\mathrm{sf}} \mathrm{x} \mathrm{S}_{\mathrm{sf}}+\mathrm{P}_{\mathrm{pr}} \mathrm{x} \mathrm{S}_{\mathrm{pr}}
$$

The following factors have been considered when evaluating: wave exposure (we), land use (lu), typical shore fortification (sf), property relations of riparian zone (pr). During the evaluation I intended to determine the shore zones being potentially suitable, but - through the use - the necessity of restoration to a certain extent (e.g. in case of an intensive, lake-dependent land use it is not a near-natural shore with emergent 
macrophytes that should be developed) was also considered. Wave exposure is an important viewpoint in the evaluation, also the emergent macrophytes refer to sheltered lentic areas. In case of properties in private ownership I reckoned with limited landscaping chances. Out of the existing shore fortification forms I deemed those, requiring smaller human interventions, more advantageous (slope-rip rapping shore fortification, other shore fortification). Near-natural shores - as they do not need such interventions - have been excluded. Table 4 shows the evaluation factors, weight numbers and the qualification scores.

Table 4. Evaluation factors and qualification method while defining shore zones being suitable to change shore fortification

\begin{tabular}{c|c|c|c}
\hline Evaluation factor & Qualification & Score (P) & Weight (W) \\
\hline \multirow{3}{*}{ Wave exposure (we) } & Exposed-exposed & 1 & \\
& Protected-protected, exposed-protected & 2 & 3 \\
& Protected-exposed & 1 & \\
Land use (lu) & Lake-dependent, intensive & 2 & \multirow{2}{*}{1} \\
& Not lake-dependent, intensive & 2 & \\
Lypical shore & Not lake-dependentent, extensive & - & \\
fortification (sf) & Near-natural shore & 1 & 3 \\
& Shore-wall & 3 & \\
Property conditions & Slope-rip rapping, other fortification & 1 & \\
of riparian zone (pr) & Private property, anglers' association & 3 & 2 \\
\hline
\end{tabular}

Possible category classification: 9-14 points - less suitable to change shore fortification, 15-26 points - suitable to change shore fortification, 27 points excellently suitable to change shore fortification.

\section{Results}

It was found that $58 \%$ of the plots are slightly pressured, $37 \%$ are significantly pressured and $3 \%$ are pressured to critical extent. Fig. 1 shows the evaluation of the individual shore sections regarding pressure.

Fig. 2 shows the naturalness of the individual shore sections. $52 \%$ of the lakeshore have been modified, $30 \%$ slightly modified, $16 \%$ heavily modified and $2 \%$ are nearnatural.

Concerning the buffer-function, $48 \%$ of lakeshore has medium buffer-capacity, 34\% good buffer-capacity, $17 \%$ poor buffer-capacity, $1 \%$ excellent buffer-capacity. Fig. 3 shows the evaluation of the individual shore sections.

$26 \%$ of the lakeshore is suitable to change shore fortification, $25 \%$ are less suitable and $4 \%$ are excellently suitable. In this evaluation aspect the near-natural "shore fortification" that makes almost half (45\%) of the plots was excluded. Accordingly, the assessments show that a high percentage of lakeshore is suitable for changing present shore fortification (Fig. 4). 


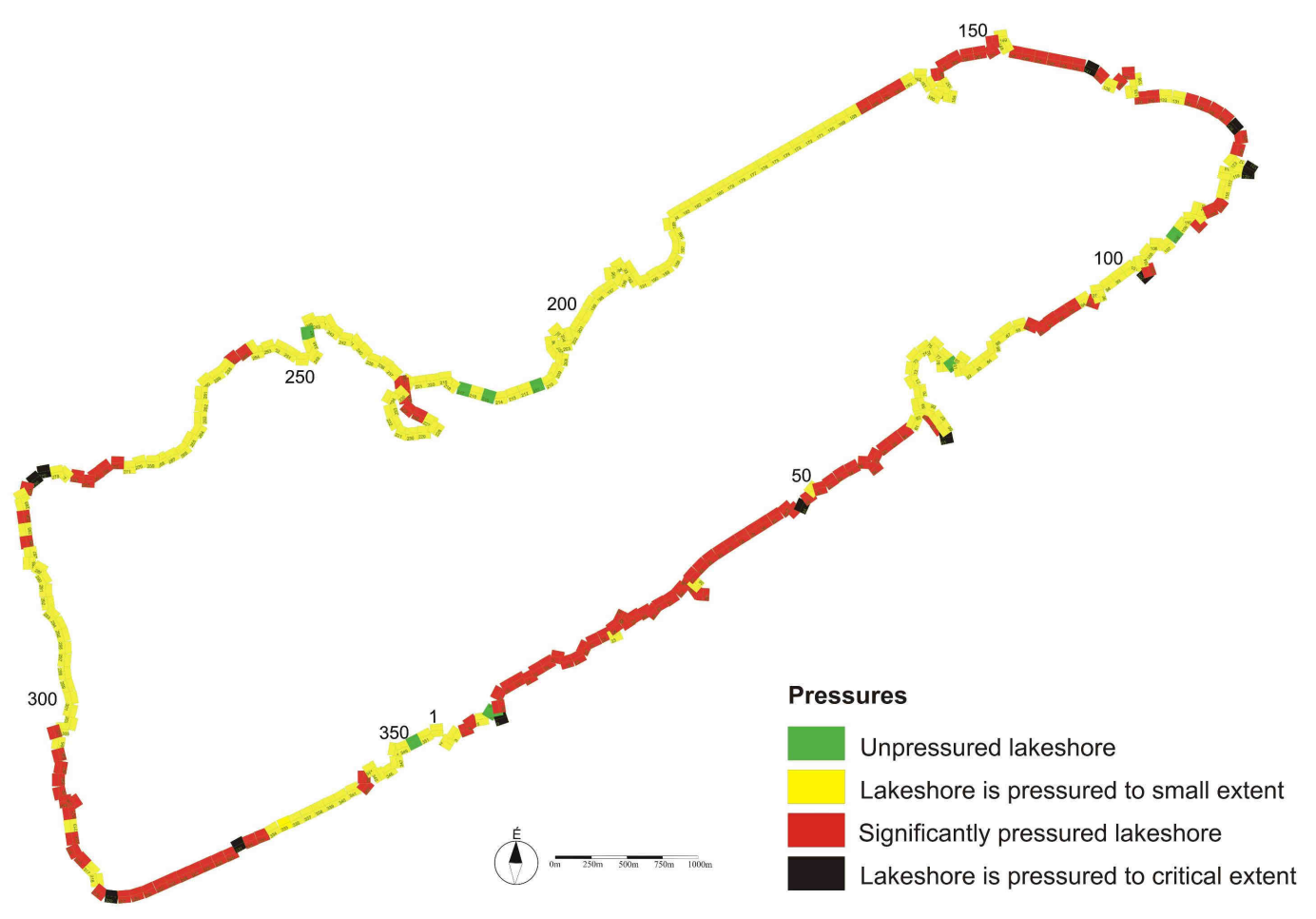

Figure 1. Lakeshore evaluation regarding pressures

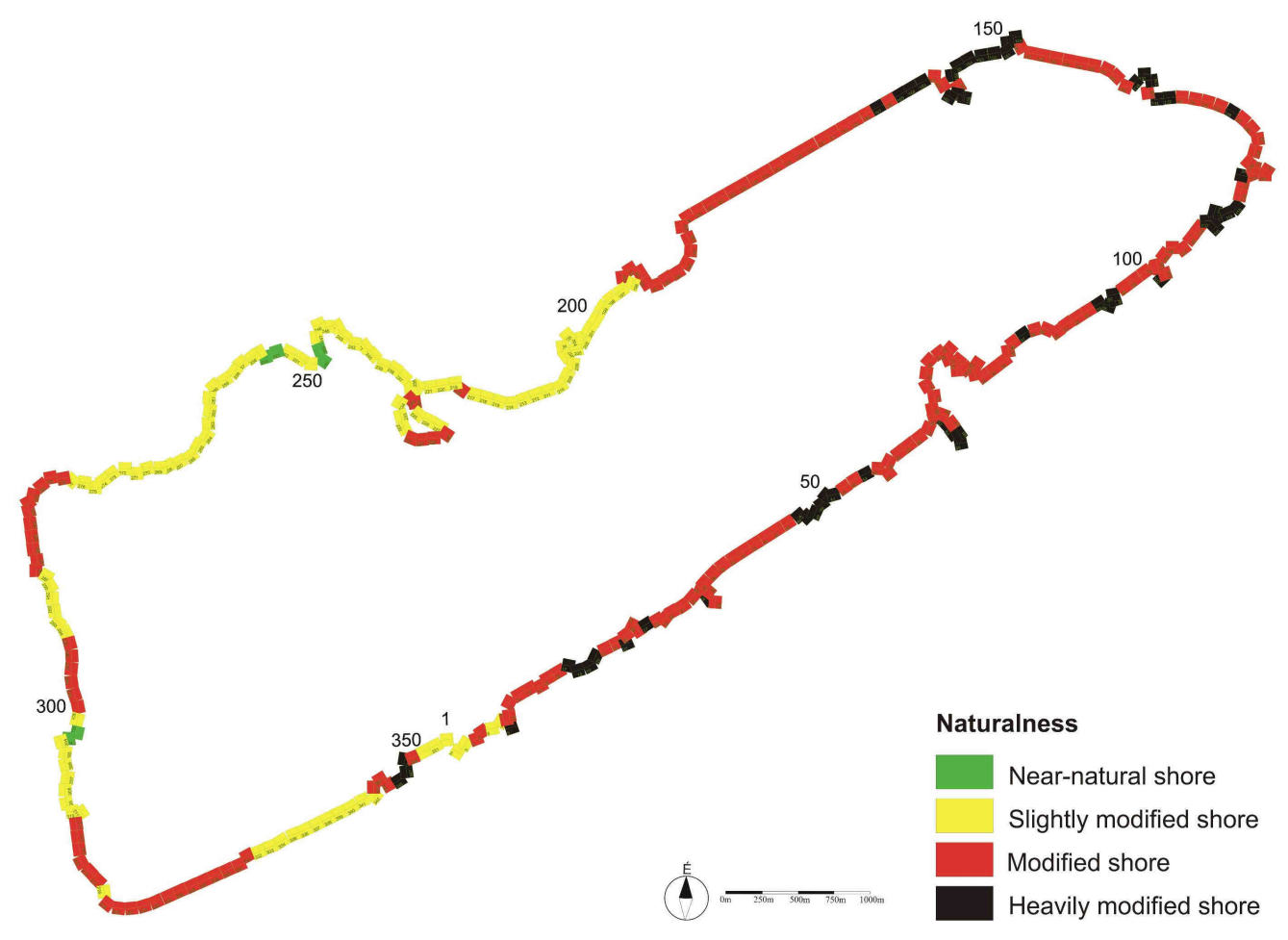

Figure 2. Lakeshore evaluation regarding naturalness

APPLIED ECOLOGY AND ENVIRONMENTAL RESEARCH 10(1): 31-46. http://www.ecology.uni-corvinus.hu • ISSN 15891623 (Print) • ISSN 17850037 (Online) (c) 2012, ALÖKI Kft., Budapest, Hungary 


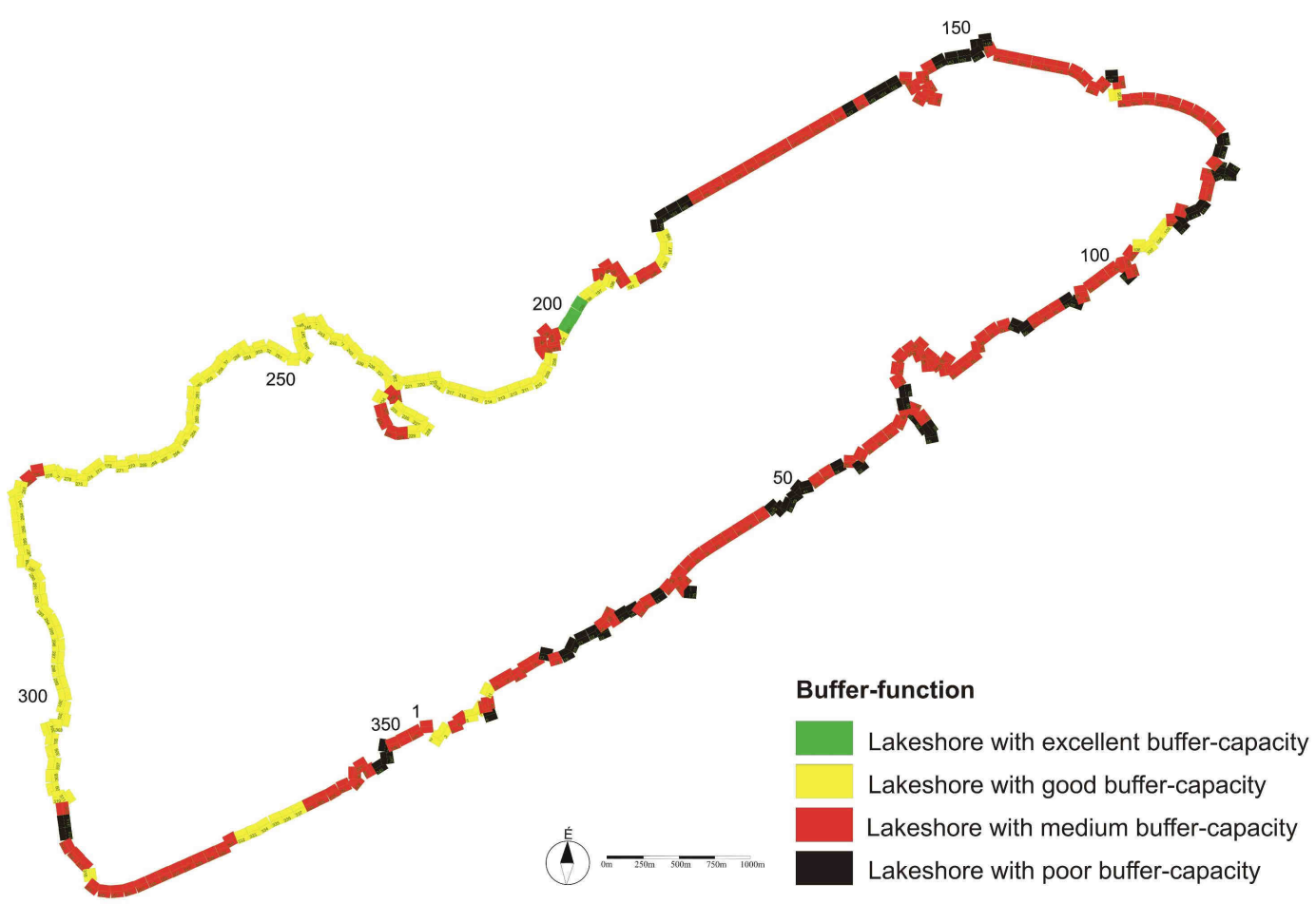

Figure 3. Lakeshore evaluation regarding buffer-function

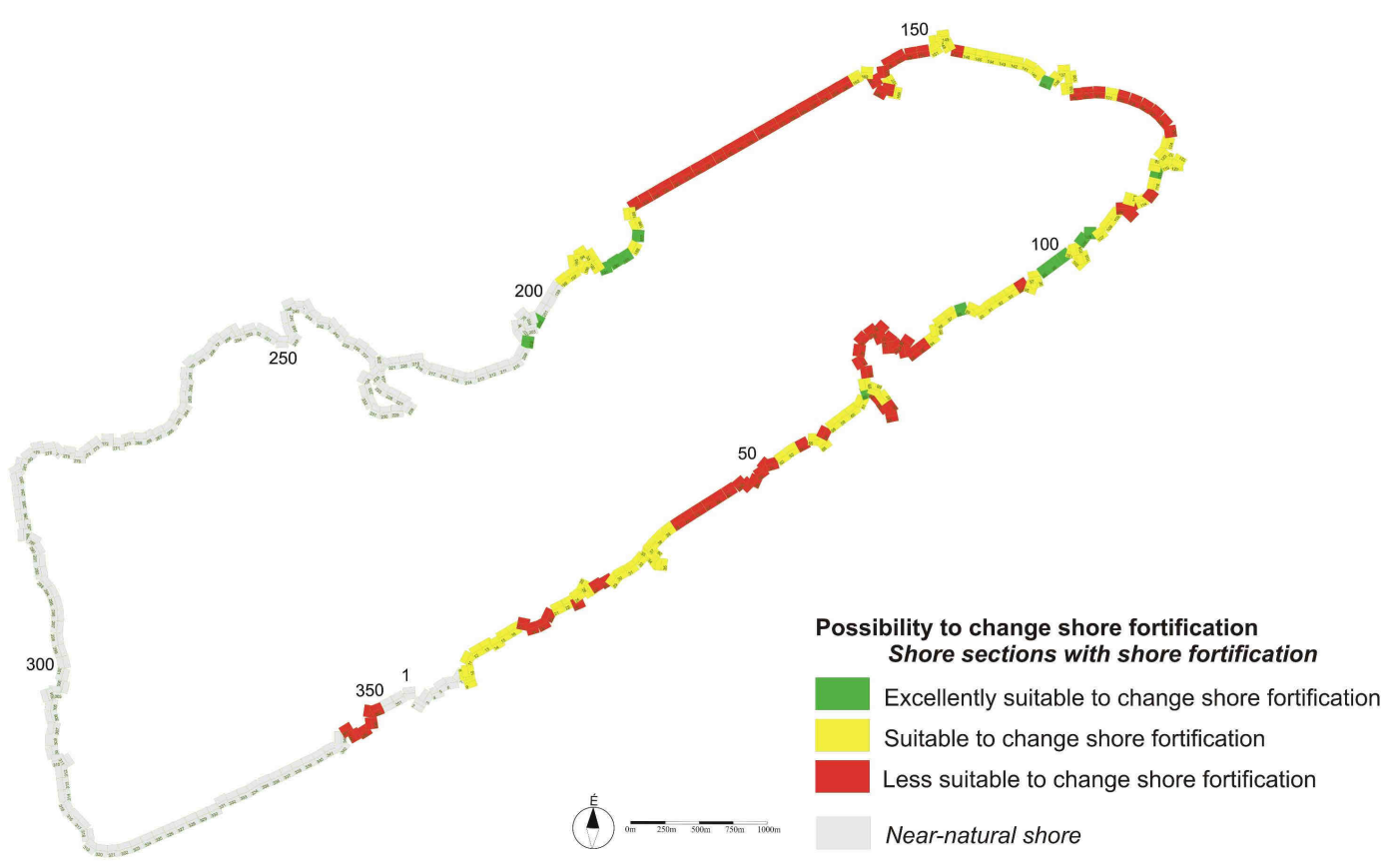

Figure 4. Lakeshore evaluation regarding change of shore fortification

APPLIED ECOLOGY AND ENVIRONMENTAL RESEARCH 10(1): 31-46. http://www.ecology.uni-corvinus.hu • ISSN 15891623 (Print) • ISSN 17850037 (Online) (c) 2012, ALÖKI Kft., Budapest, Hungary 


\section{Discussion}

\section{Pressures}

The low pressures, being characteristic for more than half of the lakeshore are partially due to the landuse peculiarities (extensive landuse, dominating greater human use in the seasons). It is also an explanation for the results that point sources of pollutions or significant linear landscape elements are present in low percentage of the assessment plots in the riparian zone. The largest, contiguous section with poor pressures can be found on the northern shore (Sukoró, plots 168-210). Large zones can be observed also on the western shore (Pákozd, plots 287-303) and on the southern shore (Gárdony, plots 66-78).

The highly pressured sections are typical mainly on the lakeshore between Agárd and Velence, on the southern part of the lake. The most areas with intensive utilization and often with lake-dependent landuse (e.g. beach, campings) belong to this category. The longest contiguous section can be found near the free-entry beach of Agárd (plots 3747). It is an unexpected result that on the southern-western shore sections there are relatively many plots with high pressures, what can be caused by the near public roads and factories.

It is only a small percentage of the plots $(12 \mathrm{pcs})$ that belong to the category "pressured to critical extent", what - in itself - may be deemed advantageous. These sections are located in many cases near boat harbours, where public roads are close to the shoreline, besides, these are the spots where point sources of pollution reach the lake (creek mouths, stormwater outlets). There are two highly pressured plots on the northern-western part of the lake, near the motorway M7 in Pákozd and at the mouth of Vereb-Pázmánd in Velence.

Regarding all the pressures of the lake the above results are much shaded by the fact that only 8 plots have been classified into the not-pressured category. These plots can be found on the southern and northern lakeshores. The individual categories appear in the most mosaic-like way in the southern-eastern and northern-western parts of the lake (near the motorway M7).

Gárdony has the largest average pressures (score: 24.02), followed by Velence (24.27), Pákozd (25.87) and Sukoró (27.9). Considering the above it is somehow unexpected that there are relatively many unpressured sections in Gárdony, and Velence has the most ones being pressured to critical extent. Sukoró is the only settlement which has no plot being pressured to critical extent.

\section{Naturalness}

The high percentage of the "modified" category is due to different human interventions of lake regulation (water-level regulation, shore- and lake-bed regulation) and to the effects of recreational utilization, based thereon. For the "modified" areas it is really characteristic that westward from the boat harbour near Bird Reserve "Madárvárta" to that in Sukoró this category is dominant, forming greater contiguous sections. The longest "modified" zone can be found in the region of the rowing course in Sukoró (plots 168-195). Because of the public road and piers near the south-west and north-west shore zone there are also "modified zones". 
The slightly modified areas dominate the northern shore of the lake, westward from the rowing course. Also the largest contiguous sections can be found here (plots 196$217,255-277$ ). On the southern shore it is the surroundings of the disposal area (used for storing dredged sediment) in Dinnyés that form longer sections (plots 332-342). The plots belonging to this category are similar in most evaluation factors despite partly being located on the filled up areas.

The "heavily modified" category can be found in most cases on the southern shore at boat harbours and ship docks. On these areas artificial elements and larger impervious surfaces are also connected with the intensive use. This is typical for the largest contiguous section from the ship dock of Óvelence to the eastern part of the rowing course (plots 149-156), mainly with shore-walls. By the western lakeshore there are no plots belonging to the "heavily modified" category.

The near-natural areas are limited to 6 plots only, i.e. there is a remarkably low percentage of the most advantageous types, similarly to pressures. This result is due on the one hand - to the small share of near-natural vegetation and - on the other hand to the large built-up area on natural soil. The zones belonging to the individual categories can be seen in the most mosaic-like way near the boat harbour in Dinnyés and next to the Bird Reserve "Madárvárta". The lakeshore involved in lake-regulation does not show any diversification as to naturalness. Among the plots 9-195 you can find exclusively "modified" and "highly modified" ones.

Regarding the administrative areas the individual settlements show significant differences. Pákozd got the highest average naturalness value (score: 31.9 ), followed by Sukoró (24.91), Gárdony (22.32) and Velence (19.26). All the near-natural areas are in Pákozd, whereas Velence has exclusively modified and highly modified zones.

It is mainly the sections near boat harbours and ship docks which have connection between pressures and naturalness and which are pressured to critical extent, being heavily modified at the same time. In case of the sections with shore-wall fortification, pressures and naturalness can be separated much better, since these zones are not pressured to critical extent necessarily, yet, mainly they are "modified". The effect of shore-walls on the zonation (and thus on the naturalness) is remarkable for the whole lake, as no emergent macrophytes exist in the water in front of them - except for 1-2 plots, there is no reed-zone being wider than $20 \mathrm{~m}$ in front of a shore-wall at Lake Velence.

\section{Buffer-function}

The category of medium buffer-capacity includes the areas involved in lakeregulation. At many plots medium buffer-capacity is due to the lack of emergent macrophytes. The longest zone, qualified for "medium" is located on the rowing course of Sukoró (plots 168-181). Although the rowing course does not have good conditions as to its shore fortification and emergent macrophytes, yet it is compensated by the cover of the riparian zone (e.g. shelter forest belt). The south-western zones, being in more near-natural status partly, are also belonging to this category.

The areas with good buffer-capacity are typical between the reed-works of Pákozd and the boat harbour in Sukoró. They form long contiguous sections between the plots 236-278 and 281-311. In these sections the advantageous results are due to the high cover of emergent macrophyte vegetation as well as of the riparian ones.

The areas with poor buffer-capacity have low cover of riparian vegetation and emergent macrophytes that are missing and they have shore-wall fortification. These 
conditions can be found in larger sections near boat harbours in many cases. The area of the northern beach of Velence also belongs to this category (plot 149-154).

Out of the 351 plots there are only 3 that have excellent buffer-capacity. This result may be caused by the fact that the combination of the clayey fill-up, considered to be good in this aspect, with high vegetation cover (especially emergent macrophytes) is very rare, as the typically more intensive utilization of filled up areas is rarely coupled with such features. The mosaic-like arrangements of different categories is characteristic first of all for the areas involved in lake-regulation. At these landscape parts longer sections with medium buffer-capacity are broken by sections with poor buffer-capacity.

In many cases sections with poorer buffer-capacity are more pressured. This comparison gives more consequences as to the ecological status of Lake Velence, than the evaluation of buffer-capacity in itself. It is characteristic first of all of the Agárd and Gárdonyfürdő regions. These areas with dominantly medium buffer-capacity are pressured at least to medium extent. This strong connection can be noticed in many cases near boat harbours (heavily modified, poor buffer-capacity). Similar connection could be found in the eastern shore section and by the south-west parts - along the main road no. 7 . The heavily modified shore sections have typically medium, or poor buffercapacity, yet, the areas with good buffer-capacity are not necessarily near-natural.

The individual administrative regions have the following average buffer-capacity: Pákozd (score: 34.21), Sukoró (27.91), Velence (24.05), Gárdony (23.87). The outstanding result of Pákozd is due to the fact that out of the 114 plots for this settlement, 93 plots have good buffer-capacity, whereas the 3 plots with excellent buffer-capacity belong to the administrative district of Sukoró.

\section{Possibility to change shore fortification}

The shore sections, deemed suitable to change shore fortification on basis of the evaluation, the longer one in Agárd (plots 8-16), Gárdony (plots 29-39) and Velence (plots 140-146) do not have optimal features in no respect for restoration, nevertheless this may be modified e.g. by a changed landuse in the future. Unfortunately there are no exact figures of the lakebed depth-conditions what is disadvantageous for the evaluation.

For the "less suitable" areas application of shore-wall is characteristic. As qualification is influenced by several factors in addition to shore fortification, shore sections with shore fortification are supposed to be similar also in their other attributes (e.g. type and intensity of landuse, wave exposure). The longest, less suitable section is on the rowing course of Sukoró. In case of "excellently suitable" areas plots are concentrated basically in two landscape parts: among the plots 185-198 in Sukoró and 95-109 in Velence there are more "excellently suitable" plots, one after another. Knowing the "neighbourhood conditions" it is mainly the shore section of Velence that can be considered to have advantageous conditions to change shore fortification (the shore section of Sukoró is located directly near the rowing course).

After having compared the results with the pressures evaluation, definite connection was found between the two indicators. The $\mathrm{a} / \mathrm{m}$ plots of the shore sections in Velence and Sukoró mainly belong to the slightly pressured category. There is no strong connection between the results of naturalness and suitability to change shore fortification. The zones that are suitable for transformation consist of modified or heavily modified plots in greater part. Buffer-capacity does not show connections with 
the above results, either. Most shore sections qualified for excellently suitable belong to Velence, followed by Sukoró and Pákozd. It is the low percentage of shore fortification, because of which one cannot find sections, being suitable for changing shore fortification, either. The significance of restoration possibilities in the administrative region of Velence is absolutely high, as this is the settlement with the least near-natural shore sections, being much pressured while having relatively few sections with good buffer-capacity.

\section{Conclusion}

The shore of Lake Velence was evaluated according to four viewpoints: pressures, naturalness, buffer-function, suitability for shore fortification. The results of the research can be applied for the landscape planning practice in several aspects. The evaluation of the shore fortification transformability can be considered during lakeshore-restoration in compliance with WFD documents of different scale nationwide and catchment subordinate unit. The other evaluation results may serve as basis for further landscape planning processes of the lake's surroundings. The results of pressure assessments can be applied to define pressures of landscape, for concepts of recreation-tourism development, to manage protected landscape parts from nature protection viewpoint (or for nature protection management plan of Bird Reserve of Lake Velence) as well as for the environment protection programs of the settlements. Many results can be regarded as disadvantageous considering landscape ecology and landscape protection what is due - in a way - to the lack of a proper regulation system. This may apply to lake-use and shore-use activities, which have not been duly coordinated (e.g. tourism forms disturbing each other), as well as to the maintaining duties. The local code typically disregards the specialities of lakeshores and cannot treat the individual appearance forms, the shore-types in a properly differentiated manner. Another main reason for problems and landuse conflicts is the lack of knowledge of lakeshore functions.

During the evaluation lacks have been found in basic researches: the non-pointsource pressures of the lake, importance of the individual shore fortification solutions for habitats are not known, besides, it is a significant deficiency that there are no exact data available on lakebed depth conditions as well as on the present status of silting up.

Also, regarding practical use of the research made on the shore of Lake Velence, it is of high importance to extend the prospectives in time, thus, the dynamic processes of lakeshore can also be evaluated (e.g. emergent macrophytes, changes of use intensity). The research can be well completed with a survey of utilization customs and demands, sustaining problems, and involving all concerned parties comprehensively (e.g. local governments, competent national park management, supervisory boards of environment-, nature protection and water affairs, managements of nature protection and water affairs, local rural development office, companies being interested in recreation-tourism services, local people, NGOs).

As further objective, applicability of this method for other medium-size, or large lakes with primary recreational utilization should be assessed. The assessment method of lakeshores' visual features is to be worked out as a part of evaluating the role that lakeshores play in landscape character. As lakes of various characters require special considerations while defining assessment methods of lakeshores, lake-classification from landscape architecture point of view is essential. 
Determination of landuse directions and priorities for the long run need a complex approach comprising the whole lake. The tasks connected with the individual shore features (giving priority to water level regulation) and with the landscape parts having various functions can be planned on the basis of this knowledge. In the future, utilization of lakeshore, landscaping, regulation and management of landzone are to be defined together. The above professional duties should be completed with a continuous development of environmental consciousness.

Acknowledgements. I have to thank Mr. Péter Csima (Department of Landscape Protection and Reclamation, Corvinus University of Budapest, Head of Department) and Mrs. Piroska Pomogyi (CentralTransdanubian Water Authority) for the help they rendered to me to write this article.

The study was prepared as part of the TÁMOP-4.2.1/B-09/1/KMR-2010-0005 research project.

\section{REFERENCES}

[1] Adamus, P.R., Stockwell, L.T., Clairain, Ellis J., Jr., Morrow, M.E., Rozas, L.P., Smith, R.D. (1991): Wetland Evaluation Technique (WET), Volume I: Literature Review and Evaluation Rationale, Technical Report WRP-DE-2. - US Army Engineer Waterways Experiment Station, Vicksburg

[2] Bain, M.B., Harig, A.L., Loucks, D.P., Goforth, R.R., Mills, K.R. (2000): Wetland ecosystem protection and restoration: advances in methods for assessment and evaluation. - Environmental Science \& Policy 3: 89-98.

[3] Balaton Kiemelt Üdülőkörzet Területrendezési Terve (1998). Egyeztetési anyag. - VÁTI Magyar Regionális Fejlesztési és Urbanisztikai Kht, Budapest.

[4] Baranyi, S. (1980): A tavak hidrológiája. - VITUKI, Budapest

[5] Bendefy, L. (1971): A Velencei-tó kialakulása és fejlődéstörténete. - VITUKI, Budapest

[6] Bökfi, S., Divinyi, T., Patkós, M. (1987): Állóvizek üdülési, hasznosítási célrendszere, különös tekintettel a Velencei-tó fejlesztésére. - In: Vízkészletvédelem. Magyar Hidrológiai Társaság VII. Országos Vándorgyülés. Salgótarján 1987. június 9-11. II. kötet.

[7] Boromisza, Zs. (2010): Parti sáv értelmezési lehetőségek és lehatárolási módszerek állóvizek tájértékelésében. - 4D Tájépítészeti és kertmüvészeti folyóirat 19: 46-53.

[8] Boyd, L. (2001): Buffer zones and beyond. Wildlife uses of wetland buffer zones and their protection under the Massachusetts Wetland Protection Act. - Department of Natural Resources Conservation, University of Massachusetts, Amherst

[9] Brinson, M.B., Malvárez, A.I. (2002): Temperate freshwater wetlands: types, status and threats. - Environmental Conservation 29 (2): 115-133.

[10] Common Implementation Strategy (CIS) for the Water Framework Directiv (2000/60/EC). Wetlands Horizontal Guidance. Horizontal Guidance Document on the Role of Wetlands in the Water Framework Directive. Final Draft (2003).

[11] Cowardin, L.M., Carter, V., Golet, F.C. , LaRoe, E.T. (1979): Classification of wetlands and deepwater habitats of the United States. - U. S. Department of the Interior, Fish and Wildlife Service, Washington

[12] Csima, P., Göncz, A. (2003): A területrendezési tervek tájterhelési és táj-terhelhetőségi vizsgálatának módszere. Tervezési útmutató. - SZIE Tájvédelmi és Tájrehabilitációs Tanszék - VÁTI Kht, Budapest

[13] Davies, P.M., Lane, J.A.K (1996): The impact of vegetated buffer zones on water and nutrient flow into Lake Clifton, Western Australia. - Journal of the Royal Society of Western Australia 79: 156-160. 
[14] Engel, S., Pederson Jr., J.L. (1998): The construction, aesthetic and effects of lakeshore development: a literature review. Research report 177. - Wisconsin Department of Natural Resources, Madison

[15] Entz, G., Sebestyén, O. (1942): A Balaton élete. Királyi Magyar Természettudományi Társulat, Budapest

[16] Felföldy, L. (1981): A vizek környezettana. Általános hidrobiológia. - Mezőgazdasági Kiadó, Budapest

[17] Felföldy, L. (1986): A tavak nádasainak vízminőségi jelentősége és jövője. In. Magyar Hidrológiai Társaság VI. Országos Vándorgyülés. I. szekció. A tavak élete és vízgazdálkodása. Hévíz. 1986. június 17-19.

[18] Fennessy, M. S., Jacobs, A.D., Kentula, M.E. (2007): An evaluation of rapid methods for assesssing the ecological condition of wetlands. - Wetlands 27( 3): 543-560.

[19] Fischer, R.A., Fischenich, J.C. (2000): Desgin recommendations for ripatian corridors and vegetated buffer strips. - US Army Engineer Research and Development Center, Environmental Laboratory, Vicksburg

[20] Furgala-Selezniow, G., Skrzypczak, A., Kajko, A., Mamcarz, A. (2011): Characterization of the management of the shore zone of Ukiel Lake (Olsztyn, Poland). - In. Móra, A., Bíró, P. (ed.): Programme and abstracts of conference on „Ecological problems of tourist lakes”. 20-23 June, 2011, Tihany Hungary. Balaton Limnological Research Institute of the Hungarian Academy of Sciences.

[21] Goda, P. (1991): Folyószabályozás, tószabályozás, árvízvédelem, ármentesítés. - Typotex Kft., Budapest

[22] Innis, S.A., Naiman, R.J., Elliott, S.R. (2000): Indicator and assessment methods for measuring the ecological integrity of semi-wetland terrestrial environments. Hydrobiologia 422/423: 111-131.

[23] Karászi, K. (ed., 1984): A Velencei-tó rekreációja. - Vízgazdálkodási Intézet, Budapest

[24] KDTVIZIG (1974): A Velencei-tó part és mederrendezés munkáinak általános terve (1974). - Közép-dunántúli Vízügyi Igazgatóság (KDTVIZIG), Székesfehérvár

[25] KSzI (1998): A Kiskörei-tározó (Tisza-tó) víztereinek és partjainak környezethasználati terve és szabályzata I. ütem. - Kulturmérnöki Szolgáltató Iroda Bt, Budapest.

[26] KvVM (2007): Nemzeti Fenntartható Fejlődési Stratégia (2007). - Nemzeti Fejlesztési Ügynökség, Környezetvédelmi és Vízügyi Minisztérium (KvVM), Budapestplaces

[27] KvVM (2008): Nemzeti Éghajlatváltozási Stratégia 2008-25. - Környezetvédelmi és Vízügyi Minisztérium (KvVM), Budapest

[28] KvVM (2009a): Nemzeti Környezetvédelmi Program 2009-14. - Környezetvédelmi és Vízügyi Minisztérium (KvVM), Budapest

[29] KvVM (2009b): A Víz Keretirányelv hazai megvalósítása. Vízgyüjtő-gazdálkodási terv. A Duna-vízgyüjtő magyarországi része - Környezetvédelmi és Vízügyi Minisztérium $(\mathrm{KvVM})$, Vízügyi és Környezetvédelmi Központi Igazgatóság, Budapest

[30] Lehner, B., Döll, P. (2004): Development and validation of global database of lakes, reservoirs and wetlands. - Journal of Hydrology 296: 1-22.

[31] Ligeti, L. (1976): A tószabályozás alapvető szempontjai. In. Balaton ankét. Keszthely 1976. szeptember 30 - október 1. Magyar Hidrológiai Társaság, Budapest.

[32] Löffler, H. (1990): Imapct by man. - In. Jorgensen, S.E. (ed.): Guidelines of lake management. Vol. 3. Lakeshore management, UNEP, ILEC Series

[33] McPherson, S., Hlushak, D. (2008): Windermere Lake Fisheries and Wildlife Habitat Assessment. Consultant report prepared for the East Kootenay Integrated Lake Management Partnership. - Interior Reforestation Co. Ltd., Cranbrook

[34] Ness, K.L. (2006): The effets of shoreline development on lake littoral and riparian habitats: are shoreline protection regulations enough? Thesis. - Submitted in Partial Fulfillment of the Requirements for the Degree of Master of Science, University of Maine, Orono 
[35] Ostendorp, W. (2004): New approaches to integrated quality assessment of lakeshores. Limnologica 34: 160-166.

[36] Ostendorp, W., Dienst, M., Jacoby, H., Kramer, I., Peintinger, M.s, Schmieder, K., Werner, S. (2004): General Framework for a Professional Evaluation System for Lakeshore Conservation and Water Body Protection, using Lake Constance as an Example. - Expertise of the Arbeitsgruppe Bodenseeufer (AGBU) for the BodenseeStiftung and the Global Nature Fund, Radolfzell, Constance

[37] Perleberg, D., Radomski, P., Woizeschke, K., Thompson, K., Perry, P., Carlson, A. (2009): Minnesota's sensitive lakeshore identification manual: a conservation strategy for Minnesota' lakeshores. - Minnesota Division of Ecological Resources, Minnesota Department of Natural Resources, St. Paul

[38] Pieczynska, E. (1990): Litoral habitats and communities. - In. Jorgensen, S. E. (ed.): Guidelines of lake management. Vol. 3. Lakeshore management, UNEP, ILEC Series

[39] Rowan, J.S. (2008): Lake habitat survey in the United Kingdom. Field survey guidance manual. Version 4. - The Scottland and Norther Ireland Forum for Environmental Research (SNIFFER), Edinburgh

[40] Sallay, Á., Boromisza, Zs. (2011): Partfelmérés a délegyházi bányatavaknál. Tájökológiai Lapok 9(1): 87-98.

[41] Schmieder, K. (2004): European lakeshores in danger - concepts for a sustainable develpment. - Limnologica 34: 3-14.

[42] Sebestyén, O. (1943): A parti öv jelentősége a tó életében. pp. 301-308. - In. Entz Géza (ed.): A Magyar Biológiai Kutatóintézet munkái. XV. Kötet. Magyar Biológiai Kutatóintézet, Tihany.

[43] Sebestyén, O. (1957): Parti tanulmány. Klny. -MTA Tihanyi Biológiai Kutatóintézetének évkönyvéből, Akadémiai Kiadó, Tihany

[44] Sebestyén, O. (1963): Bevezetés a limnológiába. A belvizek életéről. - Akadémiai Kiadó, Budapest

[45] Siligardi, M., Bernabi, S., Cappelletti, C., Ciutti, F., Dallafior, V., Dalmiglio, A., Fabiani, C., Mancini, L., Monauni, C., Pozzi, S., Scardi, M., Tancioni, L., Zennaro, B. (2010): Lake shorezone functionality index (SFI). A tool for the definition of ecological quality as indicated by Directive 2000/60/CE. - Autonomous Province of Trento, Provincial Environmental Protection Agency, Trento

[46] Smith, R.D., Ammann, A., Bartoldus, C., Brinson, M.B. (1995): An approach for assessing wetland functions using hydrogeomorphic classification, reference wetlands, and functional indices. Wetlands Research Program Technical Report. - US Army Corps of Engineers, Waterways Experiment Station, Washington

[47] Strayer, D.L., Findley, S.E.G. (2010): Ecology of freshwater shore zones. - Wetland Science 72: 127-163.

[48] Szappanos, Z. (1978): A tószabályozás fejlesztése. - In. Kovács, D. (ed.): Árvízvédelem, folyó- és tószabályozás, víziutak Magyarországon. Országos Vízügyi Hivatal, Budapest

[49] Szilágyi, F., Szabó, Sz., Mándoki, M. (1989): Restoration of Lake Velence. - In. Saláni, J., Heródek, S. (ed.): Conservation and Management of lakes. Symposia Biologica Hungarica Vol. 38. Akadémiai Kiadó, Budapest

[50] Tóth, L. (1982): A parti zóna szerepe a Balaton tápanyagforgalmában. - VITUKI, Vízminőségvédelmi Intézet, Budapest

[51] USEPA (2007): Survey of the Nation's Lakes. Field Operations Manual. - U.S. Environmental Protection Agency (USEPA), Washington

[52] Zorkóczy, Z. (1985): Folyó- és tószabályozás. - Pollack Mihály Müszaki Főiskola Vízgazdálkodási Intézete, Baja, Tankönyvkiadó, Budapest 